University of Nebraska - Lincoln

DigitalCommons@University of Nebraska - Lincoln

Agronomy \& Horticulture -- Faculty Publications

Agronomy and Horticulture Department

2007

\title{
Comparative Nitrogen Uptake and Distribution in Corn and Velvetleaf (Abutilon theophrasti)
}

John L. Lindquist

University of Nebraska-Lincoln, jlindquist1@unl.edu

Darren C. Barker

Pioneer Hi-Bred International, Inc., York, NE

Stevan Z. Knezevic

University of Nebraska-Lincoln, sknezevic2@unl.edu

Alexander R. Martin

University of Nebraska-Lincoln, amartin2@unl.edu

Daniel T. Walters

University of Nebraska-Lincoln, dwalters1@unl.edu

Follow this and additional works at: https://digitalcommons.unl.edu/agronomyfacpub

Part of the Plant Sciences Commons

Lindquist, John L.; Barker, Darren C.; Knezevic, Stevan Z.; Martin, Alexander R.; and Walters, Daniel T., "Comparative Nitrogen Uptake and Distribution in Corn and Velvetleaf (Abutilon theophrasti)" (2007). Agronomy \& Horticulture -- Faculty Publications. 374.

https://digitalcommons.unl.edu/agronomyfacpub/374

This Article is brought to you for free and open access by the Agronomy and Horticulture Department at DigitalCommons@University of Nebraska - Lincoln. It has been accepted for inclusion in Agronomy \& Horticulture -Faculty Publications by an authorized administrator of DigitalCommons@University of Nebraska - Lincoln. 


\title{
Comparative Nitrogen Uptake and Distribution in Corn and Velvetleaf (Abutilon theophrasti)
}

\author{
John L. Lindquist, Darren C. Barker, Stevan Z. Knezevic, Alexander R. Martin, and Daniel T. Walters*
}

\begin{abstract}
Weeds compete with crops for light, soil water, and nutrients. Nitrogen $(\mathrm{N})$ is the primary limiting soil nutrient. Forecasting the effects of $\mathrm{N}$ on growth, development, and interplant competition requires accurate prediction of $\mathrm{N}$ uptake and distribution within plants. Field studies were conducted in 1999 and 2000 to determine the effects of variable N addition on monoculture corn and velvetleaf $\mathrm{N}$ uptake, the relationship between plant $\mathrm{N}$ concentration $([\mathrm{N}])$ and total biomass, the fraction of $\mathrm{N}$ partitioned to leaves, and predicted $\mathrm{N}$ uptake and leaf $\mathrm{N}$ content. Cumulative $\mathrm{N}$ uptake of both species was generally greater in 2000 than in 1999 and tended to increase with increasing $\mathrm{N}$ addition. Corn and velvetleaf $[\mathrm{N}]$ declined with increasing biomass in both years in a predictable manner. The fraction of $\mathrm{N}$ partitioned to corn and velvetleaf leaves varied with thermal time from emergence but was not influenced by year, $\mathrm{N}$ addition, or weed density. With the use of the $[\mathrm{N}]$-biomass relationship to forecast $\mathrm{N}$ demand, cumulative corn $\mathrm{N}$ uptake was accurately predicted for three of four treatments in 1999 but was underpredicted in 2000. Velvetleaf $\mathrm{N}$ uptake was accurately predicted in all treatments in both years. Leaf $\mathrm{N}$ content $\left(\mathrm{N}_{\mathrm{L}}, \mathrm{g} \mathrm{N} \mathrm{m}^{-2}\right.$ leaf) was predicted by the fraction of $\mathrm{N}$ partitioned to leaves, predicted $\mathrm{N}$ uptake, and observed leaf area index for each species. Average deviations between predicted and observed corn $\mathrm{N}_{\mathrm{L}}$ were $<88$ and $12 \%$ of the observed values in 1999 and 2000 , respectively. Velvetleaf $\mathrm{N}_{\mathrm{L}}$ was less well predicted, with average deviations ranging from 39 to $248 \%$ of the observed values. Results of this research indicate that $\mathrm{N}$ uptake in corn and velvetleaf was driven primarily by biomass accumulation. Overall, the approaches outlined in this paper provide reasonable predictions of corn and velvetleaf $\mathrm{N}$ uptake and distribution in aboveground tissues.
\end{abstract}

Nomenclature: Velvetleaf, Abutilon theophrasti Medic. ABUTH; corn, Zea mays L. 'Pioneer 33A14'.

Key words: Growth analysis, functional equilibrium, leaf area index, nitrogen nutrition, N use efficiency.

Corn yield loss because of velvetleaf competition is highly variable (Lindquist et al. 1996). Lindquist and Mortensen (1999) argued that velvetleaf causes corn yield loss primarily through competition for light, suggesting that leaf area and plant height are important canopy characteristics that determine the outcome of corn-velvetleaf competition. Both plant height and leaf area development can be influenced by the availability and competition for belowground resources (Bonifas et al. 2005; Bonifas and Lindquist 2006; McCullough et al. 1994; Radin 1983; Zhou et al. 1997). Nitrogen $(\mathrm{N})$ addition has a positive effect on both corn and velvetleaf growth, but velvetleaf height, leaf area index (LAI), and biomass tend to respond more to $\mathrm{N}$ addition than corn (Barker et al. 2006). Therefore, Barker et al. (2006) suggested that when corn and velvetleaf emerge simultaneously in a mixture, velvetleaf competitiveness increases with increasing $\mathrm{N}$ supply.

Plants grown in mixture generally do not directly influence the physiological status of neighboring plants (with the exception of parasitic or allelopathic plants). However, plants do have a direct effect on the resources available in their immediate environment. Therefore, weeds cause crop loss indirectly through their influence on the resources required for crop growth (Goldberg 1990). Each species has a unique response to the quantity of resources available within an environment. The outcome of interplant competition is driven by the physiological mechanisms that regulate the effect of each species on a given resource and the response to the quantity of that resource available to the plant. Therefore, improving our understanding of the mechanisms of interplant competition requires detailed study of plant response to each

\footnotetext{
DOI: 10.1614 /WS-06-141.1

* First, fourth, and fifth authors: Department of Agronomy and Horticulture, University of Nebraska, Lincoln, NE 68583-0915; second author: Pioneer HiBred International, Inc., York, NE, 68467; third author: Haskell Agricultural Laboratory, University of Nebraska, Concord, NE 68728. Corresponding author's E-mail: jlindquist1@unl.edu
}

resource in the absence of the confounding effects of interspecific interactions (Lindquist 2001a).

Several models have been used to describe and predict N uptake by two general approaches (e.g., Baldwin et al. 1973; ten Berge et al. 1994, 1997; Graf et al. 1990; Hasegawa and Horie 1996; Jeuffroy et al. 2002; Kropff 1993; Lindquist 2001a; Nye and Tinker 1977; Sinclair and Muchow 1995). The first approach comes from solute transport theory, in which nutrient uptake is determined primarily by the predicted solute concentration at the root surface (Baldwin et al. 1973; Nye and Tinker 1977). The only plant-driven components of this approach are the root radius, root length density, and the "root absorbing power," a term that essentially describes solute movement across the root surface (intake) as measured on excised root segments. Aboveground biomass has no effect on uptake by this approach. The second approach is more plant centered and predicts $\mathrm{N}$ uptake as the minimum of (1) the daily $\mathrm{N}$ demand and (2) the quantity of $\mathrm{N}$ available for plant uptake (ten Berge et al. 1997). A number of models are available for predicting the quantity of $\mathrm{N}$ available for uptake (e.g., Benbi and Richter 2002; de Willigen 1991), but these are outside the scope of this research.

Nitrogen demand is not well defined, so its prediction is typically based on the limitations in $\mathrm{N}$ uptake on the basis of the current status of plant growth. We follow ten Berge et al. (1994) and Sheehy et al. (1998) and suggest that daily $\mathrm{N}$ demand can be predicted as the minimum of four critical limiting factors,

$$
\mathrm{N}_{\text {demand }}=\min \left(U_{\mathrm{N}}, U_{\mathrm{M}}, U_{\mathrm{D}}, U_{\mathrm{P}}\right)
$$

where $U_{\mathrm{N}}$ is maximum observed $\mathrm{N}$ uptake rate $(\mathrm{g} \mathrm{N}$ $\left.\mathrm{m}^{-2} \mathrm{~d}^{-1}\right) ; U_{\mathrm{P}}$ is the potential rate of $\mathrm{N}$ accumulation $(\mathrm{g} \mathrm{N}$ $\mathrm{m}^{-2}$ ground $\left.\mathrm{d}^{-1}\right) ; U_{\mathrm{M}}$ is the maximum uptake rate $(\mathrm{g} \mathrm{N}$ $\mathrm{m}^{-2} \mathrm{~d}^{-1}$ ) as limited by maximum $\mathrm{N}$ fraction per unit new dry matter (Equation 2), 


$$
U_{\mathrm{M}}=q_{\mathrm{N}} d W / d t
$$

where $q_{\mathrm{N}}\left(\mathrm{g} \mathrm{N} \mathrm{g}^{-1}\right)$ is the maximum ratio of daily $\mathrm{N}$ uptake to measured daily growth rate and $d W / d t\left(\mathrm{~g} \mathrm{~m}^{-2} \mathrm{~d}^{-1}\right)$ represents a potential growth rate; and $U_{D}$ is the $\mathrm{N}$ uptake rate $\left(\mathrm{g} \mathrm{N} \mathrm{m}^{-2} \mathrm{~d}^{-1}\right)$ as limited by the difference between potential and actual amount of $\mathrm{N}$ in existing biomass on any given day (Equation 3),

$$
U_{\mathrm{D}}=W_{\mathrm{a}}[\mathrm{N}]-\mathrm{N}_{\mathrm{a}}=\mathrm{N}_{\mathrm{p}}-\mathrm{N}_{\mathrm{a}}
$$

where $W_{\mathrm{a}}$ is aboveground biomass $\left(\mathrm{g} \mathrm{m}^{-2}\right)$ of the species, $[\mathrm{N}]$ $\left(\mathrm{g} \mathrm{N} \mathrm{g}^{-1}\right.$ ) is potential $\mathrm{N}$ concentration ( $\left.\mathrm{wt} / \mathrm{wt}\right), \mathrm{N}_{\mathrm{p}}$ is the potential $\mathrm{N}$ content of the species $\left(\mathrm{g} \mathrm{N} \mathrm{m}^{-2}\right.$ ground), and $\mathrm{N}_{\mathrm{a}}$ is actual $\mathrm{N}$ content of the species ( $\mathrm{g} \mathrm{N} \mathrm{m}^{-2}$ ground). The potential $\mathrm{N}$ concentration $([\mathrm{N}])$ can be predicted as a function of total aboveground biomass of the species $\left(W_{\mathrm{a}}, \mathrm{g} \mathrm{m}^{-2}\right)$ (Greenwood et al. 1990),

$$
[\mathrm{N}]=a W_{\mathrm{a}}^{-b}
$$

where $a$ is maximum $[\mathrm{N}]\left(5.7\right.$ and $4.1 \%[\mathrm{w} / \mathrm{w}]$ for $\mathrm{C}_{3}$ and $\mathrm{C}_{4}$ species, respectively) and $b$ is a shape coefficient ( 0.5 for both $\mathrm{C}_{3}$ and $\mathrm{C}_{4}$ species). Both $a$ and $b$ have been determined empirically for some crop species, but not for weeds (although Coleman et al. [1993] presented evidence suggesting this relationship is accurate for velvetleaf). Equation 4 can be rewritten in terms of the total potential amount of $\mathrm{N}$ accumulated in aboveground biomass $\left(\mathrm{N}_{\mathrm{p}}, \mathrm{g} \mathrm{N} \mathrm{m}^{-2}\right.$ ground area; Equation 5) (Sheehy et al. 1998).

$$
\mathrm{N}_{\mathrm{p}}=(a / 100) W^{(1-b)}, \quad\left(W \geq 100 \mathrm{~g} \mathrm{~m}^{-2}\right)
$$

Sheehy et al. (1998) argued that the potential rate of $\mathrm{N}$ accumulation $\left(U_{\mathrm{P}}, \mathrm{g} \mathrm{N} \mathrm{m}^{-2}\right.$ ground $\mathrm{d}^{-1}$ ) in aboveground biomass can then be predicted by differentiating Equation 5,

$$
\begin{gathered}
U_{\mathrm{P}}=d \mathrm{~N}_{\mathrm{p}} / d t=[(1-b) a / 100] W^{-b} d W / d t, \\
\left(W \geq 100 \mathrm{~g} \mathrm{~m}^{-2}\right)
\end{gathered}
$$

and

$$
\begin{gathered}
U_{\mathrm{P}}=d \mathrm{~N}_{\mathrm{p}} / d t=(a / 100) d W / d t+W d a / d t, \\
\left(W \leq 100 \mathrm{~g} \mathrm{~m}^{-2}\right)
\end{gathered}
$$

where we assume that $[\mathrm{N}]=a$ when $W \leq 100 \mathrm{~g} \mathrm{~m}^{-2}$ (therefore, $W d a l d t=0$ ). To get $d W / d t$, we need to know the relationship between total aboveground biomass and time (d; or thermal time, GDD), which can be measured or simulated.

A correlation between $\mathrm{CO}_{2}$ assimilation and leaf $\mathrm{N}$ content $\left(\mathrm{N}_{\mathrm{L}}, \mathrm{g} \mathrm{N} \mathrm{m}^{-2}\right.$ leaf) has frequently been observed (Hasegawa and Horie 1996; Lawlor 2002; Lindquist 2001b; Sinclair and Horie 1989) because the majority of the $\mathrm{N}$ in plant leaves is found in photosynthetic proteins (Sage and Pearcy 1987a). C 3 plants use ribulose-1,5-bisphosphate carboxylase/oxygenase (Rubisco) to initially fix $\mathrm{CO}_{2}$, whereas $\mathrm{C}_{4}$ plants use phosphoenolpyruvate (PEP) carboxylase (Ehleringer and Monson 1993). Because less $N$ is associated with PEP carboxylase than Rubisco (Brown 1978) and because $\mathrm{C}_{4}$ plants contain less Rubisco than $\mathrm{C}_{3}$ plants, their overall leaf $\mathrm{N}$ content is generally lower. Nevertheless, $\mathrm{C}_{4}$ plants maintain equal or higher photosynthetic rates than $\mathrm{C}_{3}$ plants, which means that photosynthetic $\mathrm{N}$ use efficiency, or the ratio of photosynthetic rate to $\mathrm{N}$ investment in the leaf, is greater in
$\mathrm{C}_{4}$ plants than in $\mathrm{C}_{3}$ plants (Brown 1978, 1985; Lawlor 2002; Sage and Pearcy 1987a, 1987b; Sage et al. 1987).

Because interplant competition is dependent on the relative growth rate (RGR) of each competing species (Davis and Liebman 2001; Grime 1979; Harbur and Owen 2004; Tilman 1990) and RGR is dependent on the rate of photosynthesis within their tissues, the photosynthetic efficiency of each species (along with the quantity of photosynthetic tissue) is critical to the outcome of interplant competition. Therefore, the quantity of newly acquired $\mathrm{N}$ partitioned to leaves and leaf $\mathrm{N}$ content $\left(\mathrm{N}_{\mathrm{L}}, \mathrm{g} \mathrm{N} \mathrm{m}^{-2}\right.$ leaf) is important in determining potential plant productivity (Gastal and Lemaire 2002). Although Equation 4 can be used to determine the expected $\mathrm{N}$ concentration of the entire canopy, these equations do not account for the partitioning of $\mathrm{N}$ to leaves once it is taken up. Assuming that the $\mathrm{N}$ content of leaves is proportional to the $\mathrm{N}$ content of total aboveground biomass, the fraction of $\mathrm{N}$ taken up that is partitioned to leaves at any given time or stage of growth simplifies to Equation 7,

$$
P_{\mathrm{L}}=\frac{\mathrm{N}_{\text {leaf }}}{\mathrm{N}_{\mathrm{a}}}
$$

where $\mathrm{N}_{\text {leaf }}$ and $\mathrm{N}_{\mathrm{a}}$ are the $\mathrm{N}$ content in leaves $\left(\mathrm{g} \mathrm{N} \mathrm{m}^{-2}\right.$ ground area) and in total aboveground tissues $\left(\mathrm{g} \mathrm{N} \mathrm{m}^{-2}\right.$ ground area), respectively. The empirical relationship between $P_{\mathrm{L}}$ and time can then be used to predict the $\mathrm{N}$ content of leaves at any time $t\left(\mathrm{~N}_{\mathrm{L}, t}, \mathrm{~g} \mathrm{~N} \mathrm{~m}^{-2}\right.$ leaf) using (Sinclair and Muchow 1995),

$$
\mathrm{N}_{\mathrm{L}, t}=\frac{P_{\mathrm{L}} \mathrm{N}_{\mathrm{a}, t}}{\mathrm{LAI}_{t}}
$$

where $\mathrm{N}_{\mathrm{a}, t}$ is the predicted total aboveground $\mathrm{N}$ content $(\mathrm{g} \mathrm{N}$ $\mathrm{m}^{-2}$ ) and LAI ${ }_{t}$ is the leaf area index ( $\mathrm{m}^{2}$ leaf $\mathrm{m}^{-2}$ ground), both at time $t$.

An overall goal of our research on corn and velvetleaf is to accurately predict the effects of $\mathrm{N}$ supply on plant growth and $\mathrm{N}$ utilization. The specific objectives of this research were to quantify and compare the influence of variable $\mathrm{N}$ addition on monoculture-grown corn and velvetleaf $\mathrm{N}$ uptake, the relationship between plant $\mathrm{N}$ concentration and total biomass, the fraction of $\mathrm{N}$ partitioned to leaves over time, and the predicted $\mathrm{N}$ uptake and $\mathrm{N}_{\mathrm{L}, t}$ obtained from Equations 1 through 8 , as well as the biomass and leaf area relationships presented in Barker et al. (2006).

\section{Materials and Methods}

Field Experiment. Field experiments were conducted at the Agricultural Research and Development Center near Mead, NE, in 1999 and 2000. Soil at the site was a Sharpsburg silty clay loam (fine, smectitic, mesic, Typic Argiudoll) with pH 6.7 to 6.8 and $3.3 \%$ soil organic carbon (SOC). Phosphorus (P) was broadcast applied as $0-46-0$ at a rate of $48 \mathrm{~kg} \mathrm{P} \mathrm{ha}{ }^{-1}$ in 1999 on the basis of a soil test. No P or potassium was required in 2000 . To obtain an initial estimate of the soil-available $\mathrm{N}$ in each experimental unit (EU), two $1.2-\mathrm{m}$ soil cores were pulled and partitioned into four $30-\mathrm{cm}$ depth increments. Each depth increment was homogenized and analyzed for soil nitrate and SOC content at the 
University of Nebraska Soil and Plant Analysis Laboratory by the cadmium reduction method (Brown 1998).

The experiment was designed as a randomized complete block with four $\mathrm{N}$ addition treatments. The highest $\mathrm{N}$ level was determined on the basis of a $12.5-\mathrm{Mg} \mathrm{ha}^{-1}$ corn yield goal and residual soil $\mathrm{N}$ as determined by soil tests. Nitrogen was applied as ammonium nitrate at rates of $0,45,90$, and $180 \mathrm{~kg} \mathrm{~N} \mathrm{ha}^{-1}$ and $0,60,120$, and $240 \mathrm{~kg} \mathrm{~N} \mathrm{ha}^{-1}$ in 1999 and 2000, respectively. Plants were grown in monoculture at a density of 65,800 corn plants per hectare and either 26,300 (2 plants $\mathrm{m}^{-1}$ row) or 131,600 velvetleaf plants per hectare (10 plants $\mathrm{m}^{-1}$ row). An EU was 6 by $9 \mathrm{~m}$ and 3 by $9 \mathrm{~m}$ for corn and velvetleaf, respectively, in 1999, and 6 by 10.5 and 3 by 10.5 , respectively, in 2000 .

Corn 'Pioneer 33A14' and velvetleaf were seeded in rows spaced $0.76 \mathrm{~m}$ apart on May 3 in both 1999 and 2000. Irrigation was not available in 1999 , but was provided throughout the growing season in 2000, with approximately $51 \mathrm{~mm}$ of water applied once every 2 to 3 wk. Additional cultural practices were reported in Barker et al. (2006).

Data Collection. Destructive plant samples were periodically taken in each EU to quantify crop and weed growth and canopy dynamics. The first sample was taken on May 24, 1999, and May 15, 2000. Sampling continued weekly for the next $10 \mathrm{wk}$ and thereafter every other week, when samples were staggered among treatments (the high and low $\mathrm{N}$ application treatments were taken one week and the two middle $\mathrm{N}$ treatments the next). Plants within a $1-\mathrm{m}$ section of row were sampled from the second, third, sixth, or seventh row of each EU of the corn treatments, or from the second, third, or fourth row of each velvetleaf density treatment. At least $1 \mathrm{~m}$ of row and the adjacent row were left intact between each sample area to ensure no edge effects of sampling. Development stage and plant height were determined for each plant within the sampled area before clipping plants at the soil surface. Plants were then separated into stems, leaves, dead leaves, and reproductive tissues, and green leaf area was determined with an area meter. ${ }^{1}$ Tissues were then dried at $60 \mathrm{C}$ to constant weight. Dry tissue samples were then ground to a maximum fineness of $1 \mathrm{~mm}$ and a representative sample was sent to the University of Nebraska Soil and Plant Analysis Laboratory to determine percent N concentration $^{2}$ of each sample.

Data Analysis. Actual $\mathrm{N}$ content (g N m${ }^{-2}$ ground) of an organ group (leaves, dead leaves, stems, reproductive tissues) was calculated as the product of the biomass of that organ group $\left(\mathrm{g} \mathrm{m}^{-2}\right)$ on a given sampling date and its $[\mathrm{N}]$. Total aboveground $\mathrm{N}$ content $\left(\mathrm{N}_{\mathrm{a}}, \mathrm{g} \mathrm{N} \mathrm{m}^{-2}\right)$ was calculated as the sum of the $\mathrm{N}$ content of the organ groups. Therefore, $\mathrm{N}_{\mathrm{a}}$ calculated over time is equivalent to the cumulative $\mathrm{N}$ uptake ( $U_{\mathrm{a}}, \mathrm{g} \mathrm{N} \mathrm{m}^{-2}$ ground), which was defined as a function of days after emergence (DAE) with the logistic function of Equation 9,

$$
U_{\mathrm{a}}=\frac{U_{\max }}{1+\exp (c-d \mathrm{DAE})}
$$

where $U_{\max }$ is maximum $\mathrm{N}$ uptake and $c$ and $d$ are shape coefficients. Equation 9 was fitted to measured uptake from each EU with the nonlinear regression analysis of $S^{2} S^{3}$ PROC NLIN to estimate values for $U_{\max }, c$, and $d$ for each EU. The ratio $c l d$, which defines the time of maximum absolute $\mathrm{N}$ uptake, and maximum absolute $\mathrm{N}$ uptake rate $\left(U_{\mathrm{N}}=U_{\max } d l\right.$ 4) were also calculated for each EU. Resulting estimates of $U_{\max }, c, d, c l d$, and $U_{\mathrm{N}}$ were subjected to ANOVA with PROC MIXED ${ }^{3}$ to test the difference between $\mathrm{N}$ treatments for corn and between $\mathrm{N}$ and density treatments for velvetleaf. PROC MIXED was used to compute least squares means, standard errors, and the difference between least squares means with an LSD-like pairwise $t$ test to test for treatment differences at the $\alpha=0.05$ level. Estimates of $q_{\mathrm{N}}\left(\left[d U_{\mathrm{a}}\right)\right.$ $d t]\left[d W_{\mathrm{a}} / d t\right]$ ) (Equation 2) were calculated as the ratio between the derivative of Equation 9 with respect to time and the derivative of the same equation fit to cumulative biomass over time (DAE) and plotted as a function of time (DAE). An overall maximum value was identified for each species and used as an estimate of $q_{\mathrm{N}}$.

Nitrogen concentration $([\mathrm{N}])$ of corn and velvetleaf in total aboveground tissue as a function of total aboveground biomass was compared to that proposed by Greenwood et al. (1990) by comparing the residual mean square error (rmse) for the fit of Equation 4 on observed $[\mathrm{N}]$ as a function of observed total aboveground biomass with the residual mean square error (rmse1) for the difference between observed [N] and the Greenwood et al. (1990) curve. rmse1 $=(O-P)^{2} / n$, where $O$ is the actual observed $\mathrm{N}$ concentration in tissues at a given sampling date; $P$ is the predicted $\mathrm{N}$ concentration in tissue for that date obtained by Equation 4, with $a=410$ and 570 for corn and velvetleaf, respectively; $b=0.5$ for both species; and $n$ is the sample size. The two rmse values were compared with an $F$ test, where $F=\mathrm{rmse1} / \mathrm{rmse}$ (Montgomery 1991). A significant $F$ value indicates that rmsel $>$ rmse or that the Greenwood et al. (1990) relationship does not adequately predict the observed $[\mathrm{N}]$.

To determine $\mathrm{N}$ partitioning to leaves $\left(P_{\mathrm{L}}\right)$, the ratio between $\mathrm{N}$ content of leaves and $\mathrm{N}$ content of total aboveground tissue (Equation 7) was plotted against thermal time (GDD), and the relationships were compared among $\mathrm{N}$ treatments and plant density (for velvetleaf). If no differences were observed among treatments, a single equation was fit to all data for each species.

Corn and velvetleaf cumulative potential $\mathrm{N}$ demand was predicted by Equation 1, where $U_{\mathrm{N}}$ was the maximum $\mathrm{N}$ uptake rate $\left(U_{\mathrm{N}}=U_{\max } d / 4, \mathrm{~g} \mathrm{~N} \mathrm{~m}^{-2} \mathrm{~d}^{-1}\right)$ obtained from the fit of Equation 9 on cumulative $\mathrm{N}$ uptake over time (Tables 1 and 2); $U_{\mathrm{M}}$ was calculated from the derivative of Equation 9, fit to cumulative biomass $(d W / d t)$ over time (d) and $q_{\mathrm{N}}$ values obtained as described above; $U_{\mathrm{D}}$ was calculated from Equation 3, where $\mathrm{N}_{\mathrm{p}}$ was obtained from Equation 5 and $\mathrm{N}_{\mathrm{a}}$ was calculated as the predicted $\mathrm{N}$ content from the previous day (as would occur in any simulation model); and $U_{\mathrm{P}}$ was calculated from Equation 6, with the Greenwood et al. (1990) parameter values for $a$ and $b$ and the derivative of Equation 9 fit to cumulative biomass $(d W / d t)$ over time (d). We used time in days for this analysis, but thermal time (GDD) for the analysis of fraction $\mathrm{N}$ partitioning, because although most simulation models are driven by thermal time, they function on a daily time step. Therefore, rate parameters used to limit $\mathrm{N}$ demand on a given day will necessarily be reported in units of $\mathrm{d}^{-1}$, whereas the fraction of $\mathrm{N}$ in leaves will naturally vary with development stage, which is driven by thermal time. From these calculations, predicted $\mathrm{N}$ uptake is equivalent to predicted $\mathrm{N}$ demand, assuming that the quantity of $\mathrm{N}$ available for uptake is always sufficient to meet that demand. This certainly might not be the case, but we did not 
Table 1. Estimates of parameters from the fit of Equation 9 (maximum $\mathrm{N}$ uptake $\left[U_{\max }\right], c, d$, time of maximum $\mathrm{N}$ uptake $[c l d]$, and maximum absolute $\mathrm{N}$ uptake rate $\left[U_{\mathrm{N}}\right]$ to observed corn $\mathrm{N}$ uptake over time [days after emergence]) and their variation among $\mathrm{N}$ addition treatments $\left(\mathrm{N}_{\mathrm{trt}}\right)$ in 1999 and $2000{ }^{\mathrm{a}}$

\begin{tabular}{|c|c|c|c|c|c|c|c|c|}
\hline Year & $\mathrm{N}_{\mathrm{trt}}$ & $U_{\max }$ & $c$ & $d$ & $c l d$ & $U_{\mathrm{N}}$ & rmse $(v)^{\mathrm{b}}$ & $F^{\mathrm{c}}$ \\
\hline & $\mathrm{kg} \mathrm{N} \mathrm{ha}^{-1}$ & $\mathrm{~g} \mathrm{~N} \mathrm{~m}^{-2}$ & & & d & $\mathrm{g} \mathrm{N} \mathrm{m}^{-2} \mathrm{~d}^{-1}$ & & \\
\hline 1999 & $\begin{array}{r}0 \\
45 \\
90 \\
180\end{array}$ & $\begin{array}{l}9.39 \mathrm{~d} \\
11.60 \mathrm{c} \\
14.13 \mathrm{~b} \\
21.67 \mathrm{a}\end{array}$ & $\begin{array}{l}7.89 \mathrm{a} \\
4.85 \mathrm{bc} \\
5.35 \mathrm{~b} \\
4.22 \mathrm{c}\end{array}$ & $\begin{array}{l}0.187 \mathrm{a} \\
0.114 \mathrm{c} \\
0.139 \mathrm{~b} \\
0.098 \mathrm{~d}\end{array}$ & $\begin{array}{l}47 \mathrm{a} \\
43 \mathrm{c} \\
38 \mathrm{~d} \\
45 \mathrm{~b}\end{array}$ & $\begin{array}{l}0.438 \mathrm{~b} \\
0.327 \mathrm{c} \\
0.486 \mathrm{ab} \\
0.515 \mathrm{a}\end{array}$ & $\begin{array}{l}6.065(49) \\
8.301(49) \\
9.029(49) \\
7.244(49)\end{array}$ & $\begin{array}{l}1.25 \\
1.03 \\
1.19 \\
2.99^{*}\end{array}$ \\
\hline 2000 & $\begin{array}{r}0 \\
60 \\
120 \\
240\end{array}$ & $\begin{array}{l}21.68 \mathrm{bc} \\
20.83 \mathrm{c} \\
23.70 \mathrm{ab} \\
25.26 \mathrm{a}\end{array}$ & $\begin{array}{l}3.08 \mathrm{a} \\
3.22 \mathrm{ab} \\
2.90 \mathrm{~b} \\
2.90 \mathrm{~b}\end{array}$ & $\begin{array}{l}0.066 \mathrm{ab} \\
0.075 \mathrm{a} \\
0.059 \mathrm{~b} \\
0.056 \mathrm{~b}\end{array}$ & $\begin{array}{l}50 \mathrm{a} \\
49 \mathrm{a} \\
51 \mathrm{a} \\
52 \mathrm{a}\end{array}$ & $\begin{array}{l}0.340 \mathrm{a} \\
0.359 \mathrm{a} \\
0.336 \mathrm{a} \\
0.353 \mathrm{a}\end{array}$ & $\begin{array}{r}5.499(29) \\
8.891(29) \\
8.193(29) \\
15.854(29)\end{array}$ & $\begin{array}{l}2.32^{*} \\
2.40^{*} \\
3.19^{*} \\
2.97^{*}\end{array}$ \\
\hline
\end{tabular}

${ }^{a}$ Within columns and years, means followed by different letters are significantly different at $\mathrm{P}<0.05$.

${ }^{\mathrm{b}}$ rmse, residual mean square error; $v$, degrees of freedom.

${ }^{c} F=$ rmse1/rmse, where rmse $1=(O-P)^{2} / n$, in which $O$ is the actual observed $\mathrm{N}$ in tissues at a given sampling date, $P$ is the predicted $\mathrm{N}$ in tissue for that date obtained by Equation 1, and $n$ is the sample size, and rmse is the residual mean square error for the fit of Equation 9 to observed cumulative $\mathrm{N}$ uptake over time.

* Values are significant at $\mathrm{P}<0.05$, indicating that rmse $1>$ rmse.

observe $\mathrm{N}$ availability throughout the growth period in this study. Accuracy of the predicted $\mathrm{N}$ uptake was evaluated by comparing the residual mean square error for predicted $\mathrm{N}$ uptake (rmse1) with that for the fit of Equation 9 on cumulative uptake with an $F$ test as described previously (Montgomery 1991).

Corn and velvetleaf leaf $\mathrm{N}$ content $\left(\mathrm{N}_{\mathrm{L}, t}, \mathrm{~g} \mathrm{~N} \mathrm{~m}^{-2}\right.$ leaf) was predicted by Equation 8, where $P_{\mathrm{L}}$ was obtained from the observed $P_{\mathrm{L}}$ relationship, $\mathrm{N}_{\mathrm{a}, t}$ was calculated from Equation 1, and LAI was the observed value for a given EU. Normalized deviations $[(P-O) / O]$ between predicted $(P)$ and observed $(O)$ leaf $\mathrm{N}$ content $\left(\mathrm{N}_{\mathrm{L}}, \mathrm{g} \mathrm{N} \mathrm{m}^{-2}\right.$ leaf) were then plotted as a function of observed $\mathrm{N}_{\mathrm{L}}$ for corn and velvetleaf in 1999 and 2000. The average of these normalized deviations (average error) provides an estimate similar to a coefficient of variation.

\section{Results and Discussion}

Cumulative corn $\mathrm{N}$ uptake varied with $\mathrm{N}$ treatment in each year of the study (Table 1$)$. Corn maximum $\mathrm{N}$ uptake $\left(U_{\max }\right)$ at zero $\mathrm{N}$ was $43 \%$ of that at $180 \mathrm{~kg} \mathrm{~N} \mathrm{ha}^{-1}$ treatment in 1999 (Table 1). Cumulative $\mathrm{N}$ uptake was generally greater in 2000 compared with 1999, but the change across N treatments was not as consistent as in 1999 (Figure 1). Similar trends were observed for total aboveground biomass, in which biomass was greater in 2000 compared with 1999 and maximum biomass increased with increasing $\mathrm{N}$ supply in 1999 but not in 2000 (Barker et al. 2006). Nitrogen uptake is reduced when soil water is limiting (Burns 1980; Wallace 1990). Adequate soil water was available in both years early in the growing season, but periods of drought occurred after anthesis in 1999 when no irrigation was available. This might have lead to less $\mathrm{N}$ uptake in the lower $\mathrm{N}$ treatments in 1999 compared with 2000.

Cumulative velvetleaf $\mathrm{N}$ uptake varied with $\mathrm{N}$ addition, velvetleaf density treatment, and their interaction in each year (Table 2). Maximum accumulated velvetleaf $\mathrm{N}$ uptake $\left(U_{\max }\right)$ was greater in the high compared with low plant densities in both years. The greater uptake is due to a greater aboveground biomass at the higher weed density (Barker et al. 2006).

Table 2. Estimates of parameters from the fit of Equation 9 (maximum $\mathrm{N}$ uptake $\left[U_{\max }\right], c, d$, time of maximum $\mathrm{N}$ uptake $[c l d$ ], and maximum absolute $\mathrm{N}$ uptake rate $\left[U_{\mathrm{N}}\right]$ to observed velvetleaf $\mathrm{N}$ uptake over time [days after emergence]) and their variation among velvetleaf density in monoculture (Vd, plants $\mathrm{m}^{-1}$ row) and $\mathrm{N}$ addition treatments $\left(\mathrm{N}_{\mathrm{trr}}\right)$ in 1999 and 2000. ${ }^{\mathrm{a}}$

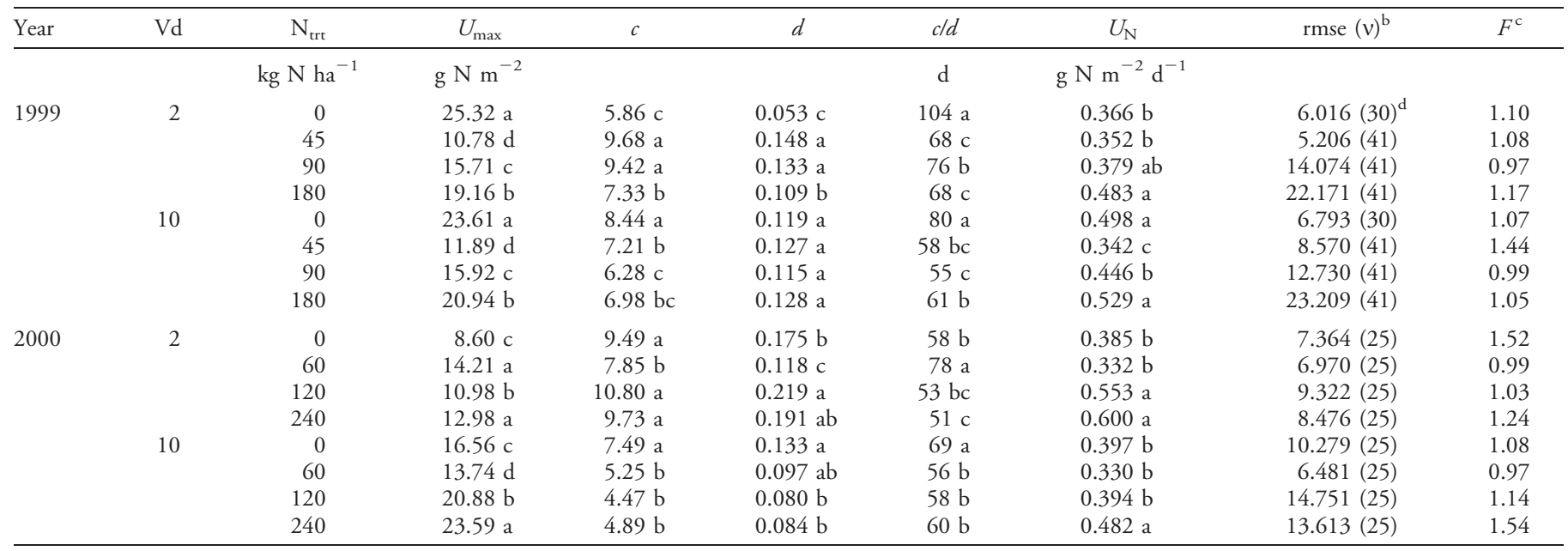

${ }^{\mathrm{a}}$ Within columns, years, and density treatment, means followed by different letters are significantly different at $\mathrm{P}<0.05$.

${ }^{b}$ rmse, residual mean square error; $v$, degrees of freedom.

${ }^{c} F=\mathrm{rmse} 1 / \mathrm{rmse}$, where rmse $1=(O-P)^{2} / n$ (where $O$ is the actual observed $\mathrm{N}$ in tissues at a given sampling date, $P$ is the predicted $\mathrm{N}$ in tissue for that date obtained using Equation 1 and $n$ is the sample size) and rmse is the residual mean square error for the fit of Equation 9 to observed cumulative $\mathrm{N}$ uptake over time. An asterisk following the $F$ value indicates it is significant at $\mathrm{p}<0.05$, indicating that rmse $1>$ rmse.

${ }^{\mathrm{d}}$ The degrees of freedom for the $0 \mathrm{~N}$ treatment was smaller in 1999 because one replicate was lost. 


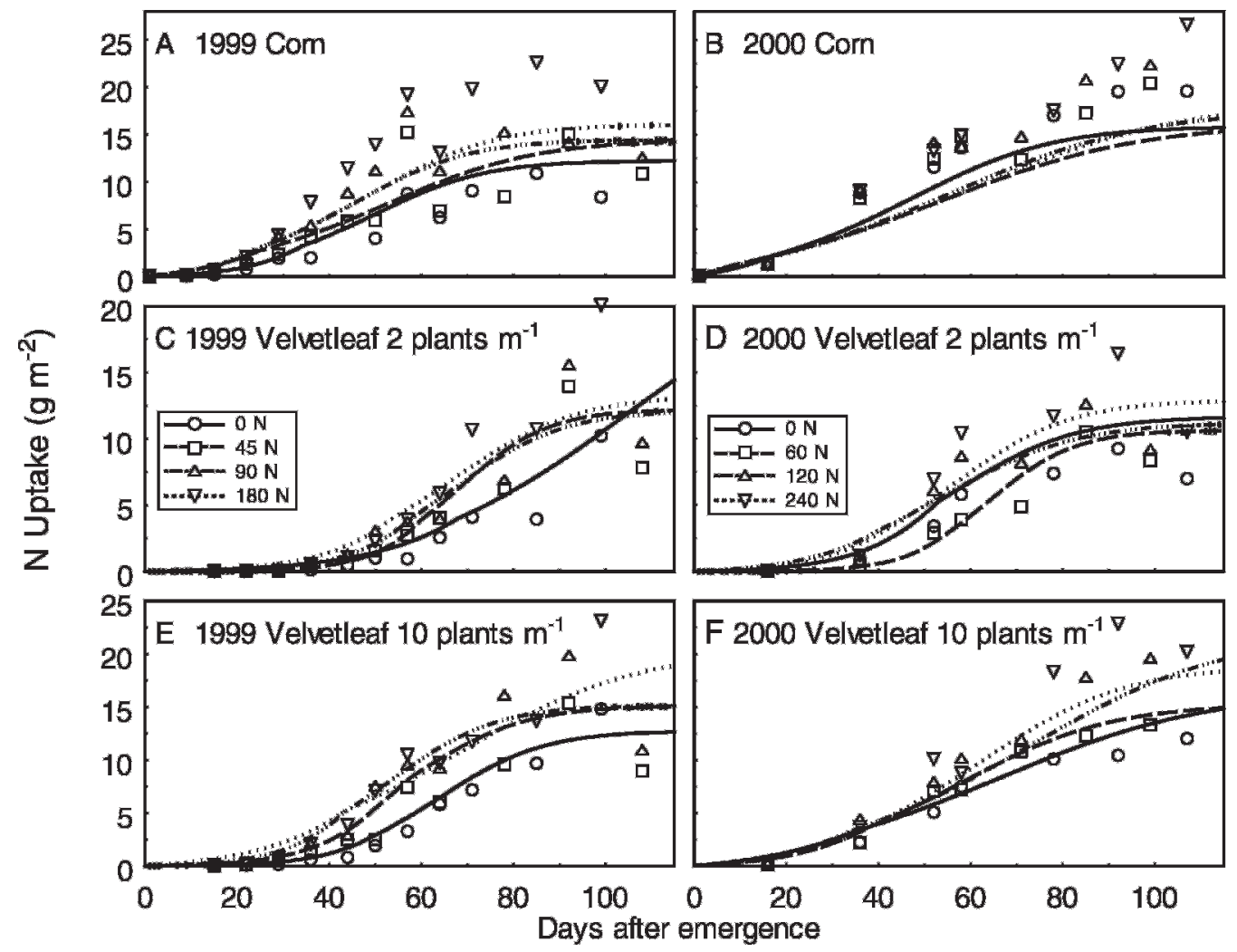

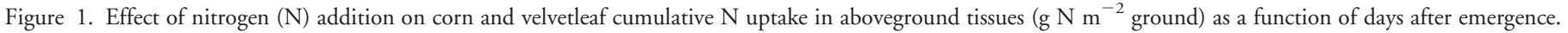

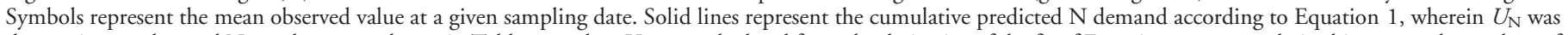

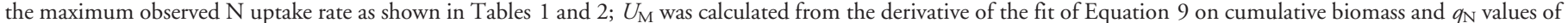

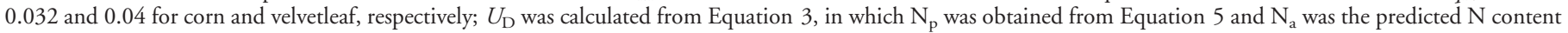
from the previous day (as would occur within a simulation model); and $U_{\mathrm{P}}$ was calculated from Equation 6.

Cumulative velvetleaf $\mathrm{N}$ uptake generally increased with increasing $\mathrm{N}$ addition in both years (Table 2; Figure 1). Differences in cumulative $\mathrm{N}$ uptake among $\mathrm{N}$ treatments are similar to observed differences in cumulative aboveground biomass (Barker et al. 2006).

The potential corn $\mathrm{N}$ uptake rate $\left(U_{\mathrm{N}}\right)$ was greatest $(0.52 \mathrm{~g}$ $\left.\mathrm{N} \mathrm{m}^{-2} \mathrm{~d}^{-1}\right)$ in the $180 \mathrm{~kg} \mathrm{~N} \mathrm{ha}^{-1}$ treatment in 1999 but did not differ among $\mathrm{N}$ treatments $\left(0.35 \mathrm{~g} \mathrm{~N} \mathrm{~m}^{-2} \mathrm{~d}^{-1}\right)$ in 2000 (Table 1). In addition, corn potential uptake rate was observed later in 2000 (49-52 DAE) compared with 1999 (38-47 DAE). Potential velvetleaf $\mathrm{N}$ uptake rate was similar to that of corn and was greatest in the highest $\mathrm{N}$ treatments in both years but did not vary across years (Table 2).

Calculation of $U_{\mathrm{M}}$ (Equation 2) includes a parameter $\left(q_{\mathrm{N}}\right)$ that defines the maximum ratio of daily $\mathrm{N}$ uptake to measured daily growth rate. To obtain estimates of $q_{\mathrm{N}}$, we calculated the ratio between the derivative of Equation 9 as fit to observed $\mathrm{N}$ uptake over time and the derivative of the same equation fit to biomass accumulation over time. A plot of the results (data not shown) showed that $q_{\mathrm{N}}$ generally declined with time, and the maximum value for corn and velvetleaf was about 0.032 and $0.040 \mathrm{~g} \mathrm{~N} \mathrm{~g}^{-1}$, respectively, which are within the ranges reported by ten Berge et al. (1997).

Corn and velvetleaf $[\mathrm{N}]$ declined with increasing aboveground biomass in both 1999 and 2000 (Figure 2). Estimates of parameters $(a$ and $b$ ) from the fit of Equation 4 on observed corn and velvetleaf $[\mathrm{N}]$ in aboveground tissues varied with $\mathrm{N}$ and velvetleaf density treatments in both years (Tables 3 and 4). Estimates of $a$ for corn increased with increasing $\mathrm{N}$ addition in both years, whereas the estimate for $b$ declined in 1999 but did not vary with $\mathrm{N}$ addition in 2000 . Estimates of $a$ for velvetleaf generally increased with increasing $\mathrm{N}$ addition and velvetleaf density, whereas estimates of $b$ varied inconsistently with $\mathrm{N}$ addition and tended to be greater in the higher density treatment. Estimates of $a$ indicate that early season corn $\mathrm{N}$ concentration ranged from 50 to $65 \mathrm{mg} \mathrm{N} \mathrm{g}^{-1}$, which is larger than that shown for corn in Greenwood et al. (1990), whereas velvetleaf [N] ranged from 42 to $55 \mathrm{mg} \mathrm{N}$ $\mathrm{g}^{-1}$, which is smaller than the values proposed for $\mathrm{C}_{3}$ species. On the other hand, estimates of the $b$ parameter for both corn and velvetleaf were smaller than those proposed in Greenwood et al. (1990). Greenwood et al. (1990) proposed their relationship on the basis of observed $[\mathrm{N}]$ values after total aboveground biomass exceeded $1 \mathrm{Mg} \mathrm{ha}^{-1}\left(100 \mathrm{~g} \mathrm{~m}^{-2}\right)$. Therefore, our different estimates of $a$ and $b$ are likely the result of the different units used $\left(\mathrm{mg} \mathrm{N} \mathrm{g}^{-1}\right.$ vs. fraction $\mathrm{N}$ and $\mathrm{g} \mathrm{m}^{-2}$ vs. $\mathrm{Mg} \mathrm{ha}{ }^{-1}$ ) and the large number of observations $<100 \mathrm{~g} \mathrm{~m}^{-2}$ that were included in our analysis. Results of an $F$ test indicate that corn $[\mathrm{N}]$ predicted with the Greenwood et al. (1990) relationship was less accurate than the regression of Equation 3 on observed $[\mathrm{N}]$ only for one treatment in 1999 (Table 3). However, except for the highest $\mathrm{N}$ addition treatment in 2000 , predicted velvetleaf $[\mathrm{N}]$ was consistently overpredicted with the Greenwood et al. (1990) curve (Table 4; Figure 2).

Predicted corn $\mathrm{N}$ uptake varied less across $\mathrm{N}$ treatments than observed $\mathrm{N}$ uptake (Figure 1). Results of the $F$ test indicate that the predicted $\mathrm{N}$ uptake by Equation 1 was less accurate than the regression of Equation 9 on observed $\mathrm{N}$ uptake over time only in the greatest $\mathrm{N}$ addition treatment in 


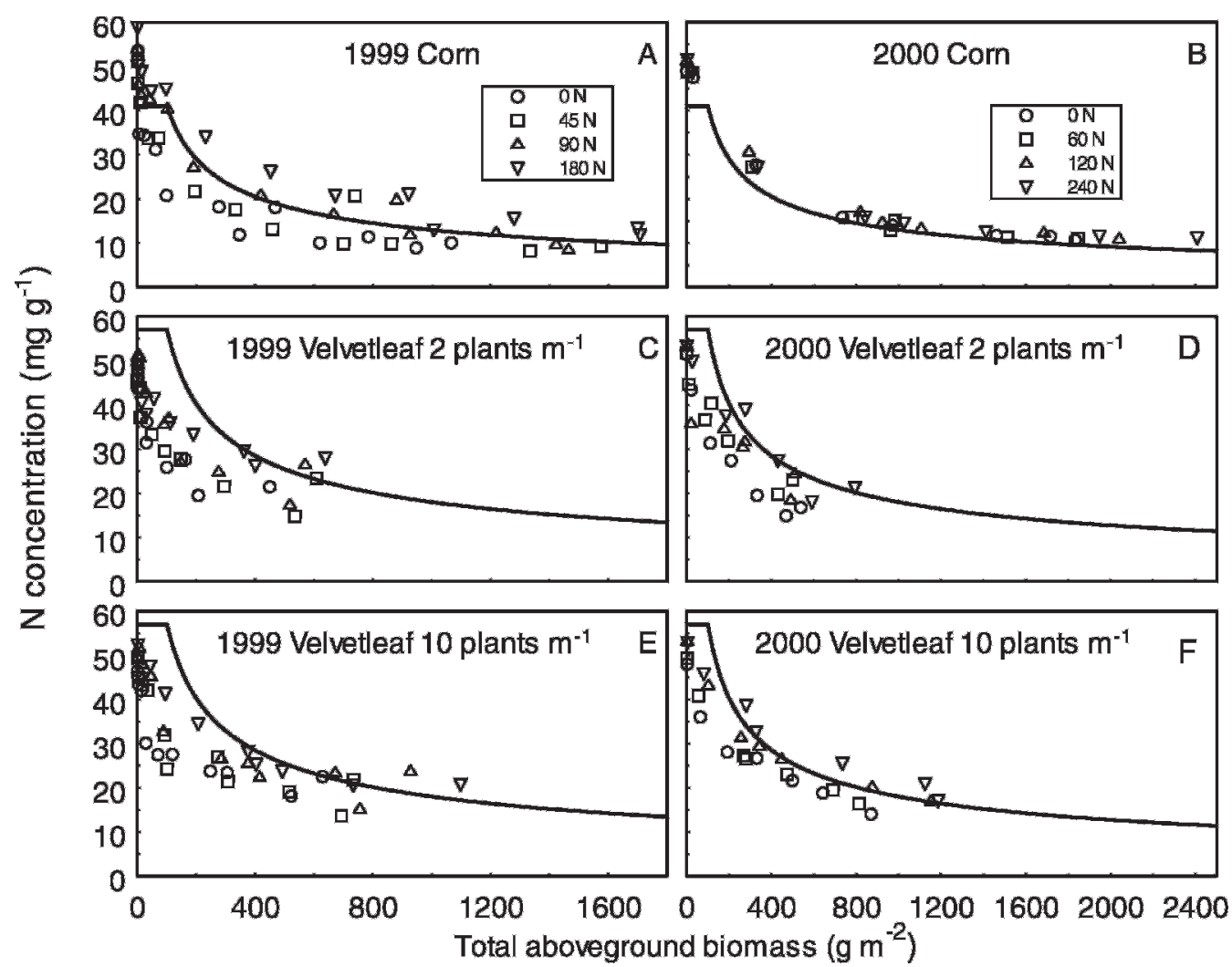

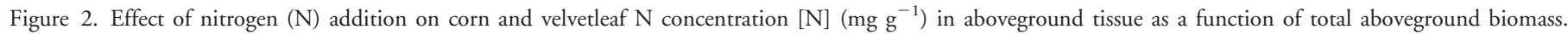

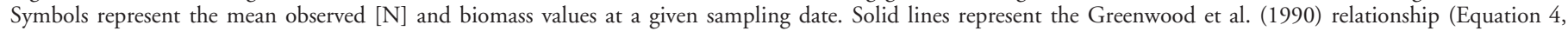
wherein $a=410$ and 570 for corn and velvetleaf, respectively, and $b=0.5$ for both species).

1999 (Table 1), in which $\mathrm{N}$ uptake was substantially underpredicted (Figure 1). Corn $\mathrm{N}$ uptake was underpredicted in all treatments in 2000 (Figure 1). Velvetleaf $\mathrm{N}$ uptake was more accurately predicted across $\mathrm{N}$ addition treatments than corn (Figure 1). Results of the $F$ test indicate that predicted velvetleaf $\mathrm{N}$ uptake was never less accurate than the regression of observed velvetleaf $\mathrm{N}$ uptake over time (Table 2; Figure 1).

Predicted $\mathrm{N}$ demand obtained from Equation 1 was typically limited by $U_{\mathrm{M}}$ from emergence until aboveground

Table 3. Estimates of parameters from the fit of Equation $4(a$ and $b$ ) on observed corn $\mathrm{N}$ concentration $([\mathrm{N}])$ in aboveground tissues in relation to total aboveground biomass in 1999 and 2000. ${ }^{\mathrm{a}}$

\begin{tabular}{cccccl}
\hline Year & $\mathrm{N}_{\text {trt }}$ & $a$ & $b$ & rmse $(v)^{\mathrm{b}}$ & \multicolumn{1}{c}{$F^{\mathrm{c}}$} \\
\hline \multirow{4}{*}{1999} & $\mathrm{~kg} \mathrm{~N} \mathrm{ha}^{-1}$ & & & & \\
& 0 & $49.5 \mathrm{~d}$ & $0.187 \mathrm{a}$ & $41.41(50)$ & $2.79^{*}$ \\
& 45 & $51.4 \mathrm{c}$ & $0.173 \mathrm{~b}$ & $55.85(50)$ & 0.97 \\
& 90 & $56.7 \mathrm{~b}$ & $0.161 \mathrm{c}$ & $76.26(50)$ & 0.55 \\
2000 & 180 & $61.9 \mathrm{a}$ & $0.150 \mathrm{~d}$ & $64.64(50)$ & 1.01 \\
& 0 & $60.4 \mathrm{c}$ & 0.1844 & $54.26(30)$ & 0.39 \\
& 60 & $61.2 \mathrm{c}$ & 0.1844 & $52.00(30)$ & 0.45 \\
& 120 & $62.9 \mathrm{~b}$ & 0.1844 & $55.77(30)$ & 0.65 \\
& 240 & $64.5 \mathrm{a}$ & 0.1844 & $50.03(30)$ & 0.68 \\
\hline
\end{tabular}

${ }^{a}$ Within columns and years, means followed by different letters are significantly different at $\mathrm{P}<0.05$.

${ }_{\mathrm{b}}^{\mathrm{c}}$ rmse, residual mean square error; $v$, degrees of freedom.

${ }^{c} F=\mathrm{rmse} 1 / \mathrm{rmse}$, where rmse $1=(O-P)^{2} / n$ (where $O$ is the actual observed $[\mathrm{N}]$ at a given sampling date, $P$ is the predicted $[\mathrm{N}]$ for that date obtained by Equation 4 with $a=4.1$ and $5.7 \%$ for corn and velvetleaf, respectively; $b=0.5$ for both species; and $n$ is the sample size) and rmse is the residual mean square error for the fit of Equation 4 to observed $[\mathrm{N}]$ over time.

* Values are significant at $\mathrm{P}<0.05$, indicating that rmse $1>$ rmse. biomass of both species reached about $100 \mathrm{~g} \mathrm{~m}^{-2}$ and thereafter was limited by $U_{\mathrm{P}}$ (Equation 6, results not shown). This result suggests that the Greenwood et al. (1990) parameters underestimate actual corn $[\mathrm{N}]$ in aboveground tissues and, subsequently, predicted $\mathrm{N}$ demand, whereas velvetleaf $[\mathrm{N}]$ was more accurately predicted. If the Greenwood et al. (1990) relationship is intended to be the upper limit of $[\mathrm{N}]$ for the species, then Figure 2 shows that corn $[\mathrm{N}]$ was indeed underestimated by the Greenwood et al. (1990) parameters. However, velvetleaf $[\mathrm{N}]$ was either overpredicted during early growth (i.e., $<200 \mathrm{~g} \mathrm{~m}^{-2}$ ) in 1999 or actual $[\mathrm{N}]$ was lower than expected even in the highest $\mathrm{N}$ addition treatment in that year.

Fraction of $\mathrm{N}$ in corn and velvetleaf leaves declined with thermal time from emergence, but was not influenced by year, $\mathrm{N}$ addition, or velvetleaf density (Figure 3). Velvetleaf partitioned a slightly larger fraction of $\mathrm{N}$ to leaves than corn (intercepts $=0.84$ vs. 0.80 , respectively) early in the season and maintained that higher fraction of $\mathrm{N}$ in leaves slightly longer. Although the initial value in Figure 3 is considerably greater than the constant value of 0.6 assumed in the corn growth model of Sinclair and Muchow (1995), the average over the season ( 0.5 from 0 to 1,450 GDD after emergence) is smaller, which might partially explain why their model tended to overpredict corn $\mathrm{N}_{\mathrm{L}, t}$.

Whole-plant corn leaf $\mathrm{N}$ content $\left(\mathrm{N}_{\mathrm{L}, t}\right)$ ranged from about 0.7 to $3.0 \mathrm{~g} \mathrm{~N} \mathrm{~m}^{-2}$ leaf and increased with increasing $\mathrm{N}$ addition in 1999 (Figure 4). However, $\mathrm{N}_{\mathrm{L}, t}$ ranged from 1.2 to $3.0 \mathrm{~g} \mathrm{~N} \mathrm{~m}^{-2}$ leaf and did not vary among $\mathrm{N}$ treatments in 2000. Nitrogen addition and velvetleaf density did not influence velvetleaf $\mathrm{N}_{\mathrm{L}, t}$ in either year (results not shown). 


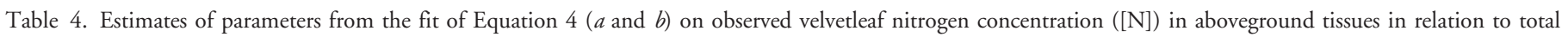
aboveground biomass in 1999 and 2000. ${ }^{a}$

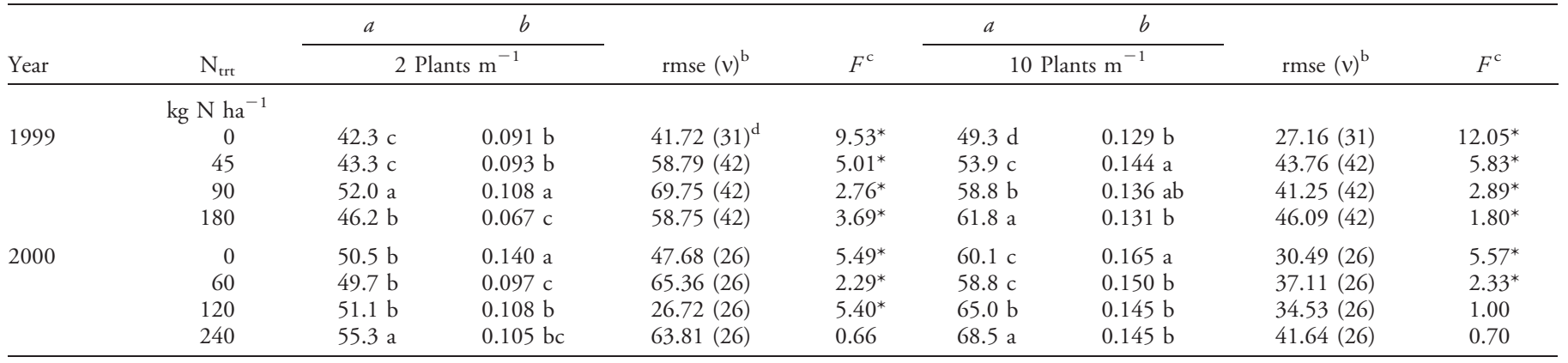

${ }^{\text {a }}$ Within columns and years, means followed by different letters are significantly different at $\mathrm{P}<0.05$.

b $r$ se, residual mean square error; $v$, degrees of freedom.

${ }^{c} F=$ rmse1/rmse, where rmse $1=(O-P)^{2} / n$ (where $O$ is the observed $[\mathrm{N}]$ at a given sampling date; $P$ is the predicted [N] for that date obtained by Equation 4 , with

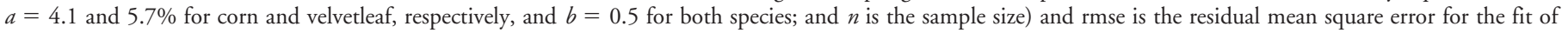
Equation 4 to observed $[\mathrm{N}]$ over time.

${ }^{d}$ Degrees of freedom for the zero $\mathrm{N}$ treatment was smaller in 1999 because one replicate was lost.

* Values are significant at $\mathrm{P}<0.05$, indicating that rmse $1>$ rmse.

Average velvetleaf $\mathrm{N}_{\mathrm{L}, t}$ was greater than that of corn in both years, which was expected because $\mathrm{C}_{3}$ species maintain greater $[\mathrm{N}]$ in the leaves than $\mathrm{C}_{4}$ plant species. Muchow and Sinclair (1994) suggested that corn yield is optimized when $\mathrm{N}_{\mathrm{L}, t}>$ $1.5 \mathrm{~g} \mathrm{~N} \mathrm{~m}^{-2}$ leaf. Corn $\mathrm{N}_{\mathrm{L}, t}$ fell below the $1.5 \mathrm{~g} \mathrm{~N} \mathrm{~m}^{-2}$ threshold during much of the 1999 growing season in the low $\mathrm{N}$ addition treatments. However, corn $\mathrm{N}_{\mathrm{L}, t}$ rarely fell below $1.5 \mathrm{~g} \mathrm{~N} \mathrm{~m}^{-2}$ in 2000. Therefore, corn appears to have been substantially more $\mathrm{N}$ stressed in 1999 than 2000. These results help explain the strong response of corn biomass and leaf area index to $\mathrm{N}$ addition in 1999, but not in 2000 (Barker et al. 2006).

Deviation between predicted and observed corn and velvetleaf leaf $\mathrm{N}$ content $\left(\mathrm{N}_{\mathrm{L}, t}\right)$ showed a tendency toward overprediction when $\mathrm{N}_{\mathrm{L}, t}$ was small, but became more accurate as $\mathrm{N}_{\mathrm{L}, t}$ increased (Figure 4). The average of those deviations is similar to a coefficient of variation and was small for corn in 2000 ( -0.12 or closer to zero) but larger in 1999, ranging from 0.34 to 0.88 (Table 5). The average of those deviations for velvetleaf $\mathrm{N}_{\mathrm{L}, t}$ was larger than that for corn in both years, but also tended to be smaller in 2000 than in 1999 (Table 5).

Results of this research indicate that corn and velvetleaf $\mathrm{N}$ uptake is driven primarily by biomass accumulation, and that $[\mathrm{N}]$ in tissue changes with aboveground biomass in a predictable manner. Use of the Greenwood et al. (1990) [N]biomass relationship as altered by Sheehy et al. (1998) to predict $\mathrm{N}$ uptake resulted in accurate predictions of corn and

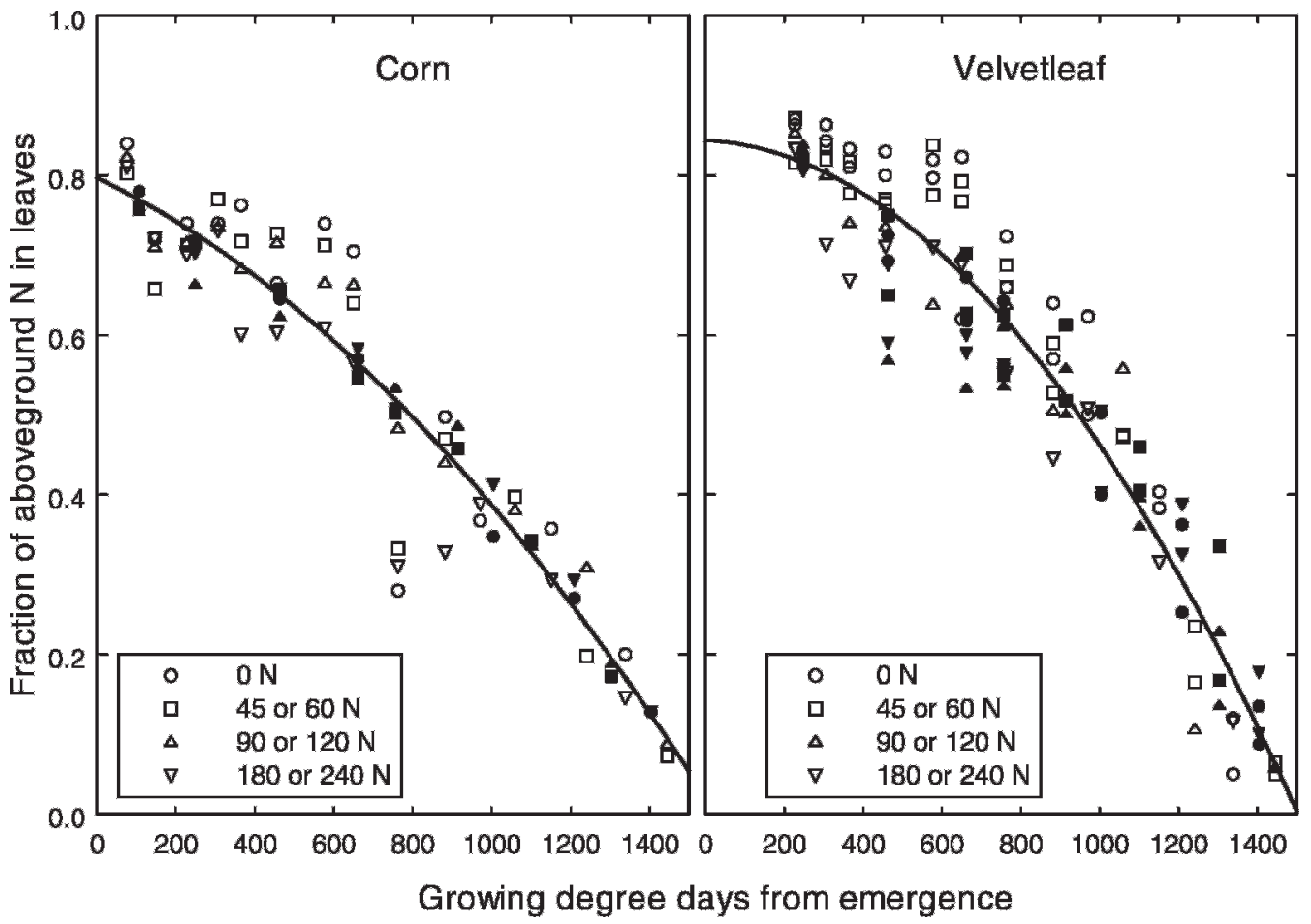

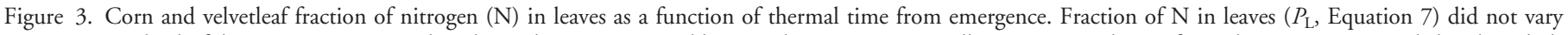

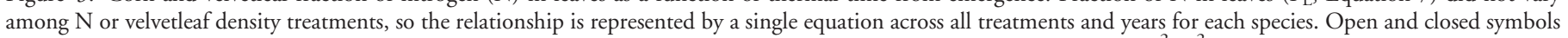

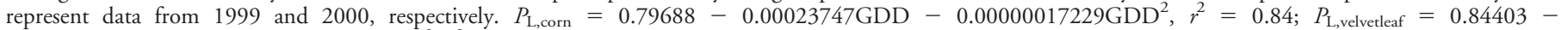
$0.00002452 \mathrm{GDD}-0.000000357407 \mathrm{GDD}^{2}, r^{2}=0.85$. 


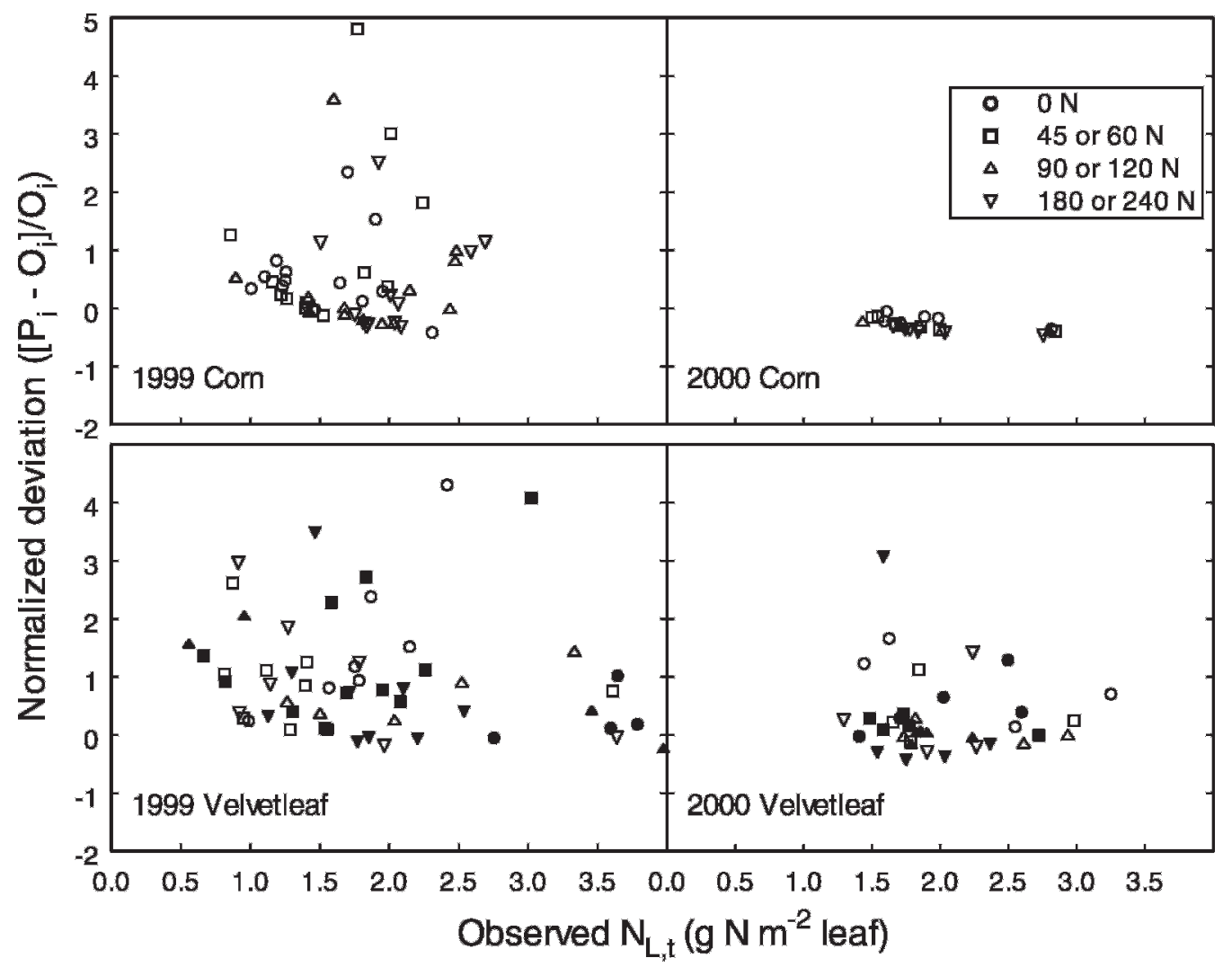

Figure 4. Normalized deviations between predicted and observed leaf nitrogen content $\left(\mathrm{N}_{\mathrm{L}}, \mathrm{g} \mathrm{N} \mathrm{m}^{-2}\right.$ leaf) plotted as a function of observed $\mathrm{N}_{\mathrm{L}}$ for corn and velvetleaf in 1999 and 2000. Predicted $\mathrm{N}_{\mathrm{L}}$ was calculated by Equation 8, wherein $P_{\mathrm{L}}$ was obtained from the relationship shown in Figure 3, $\mathrm{N}_{\mathrm{a}, t}$ was calculated from Equation 1, and LAI was the observed value. In the velvetleaf plots, open and closed symbols represent velvetleaf grown at 2 and 10 plants $\mathrm{m}^{-1}$ row, respectively.

velvetleaf $\mathrm{N}$ uptake in most cases, although the corn $[\mathrm{N}]-$ biomass relationship might need to be altered to better reflect the higher corn $[\mathrm{N}]$ observed here. The fraction of aboveground $\mathrm{N}$ found in leaves in relation to thermal time was remarkably stable across years and treatments for both species. This is useful because it appears that a single function can be used to predict the partitioning of $\mathrm{N}$ to leaves of each of these species regardless of $\mathrm{N}$ supply or plant density. Average deviations between predicted and observed corn $\mathrm{N}_{\mathrm{L}}$ were $<88$ and $12 \%$ of the observed values in 1999 and 2000, respectively. Velvetleaf $\mathrm{N}_{\mathrm{L}}$ was less well predicted, with

Table 5. Average of the normalized deviations $[(P-O) / O$ ] between predicted $(P)$ and observed $(O)$ leaf $\mathrm{N}$ content $\left(\mathrm{N}_{\mathrm{L}, t}\right)$ of monoculture-grown corn and velvetleaf. Predicted $\mathrm{N}_{\mathrm{L}, t}$ was obtained by Equation 8 , where $P_{\mathrm{L}}$ was obtained from Figure 3, $\mathrm{N}_{\mathrm{a}, t}$ was calculated by Equation 1, and LAI was the observed value for a given experimental unit.

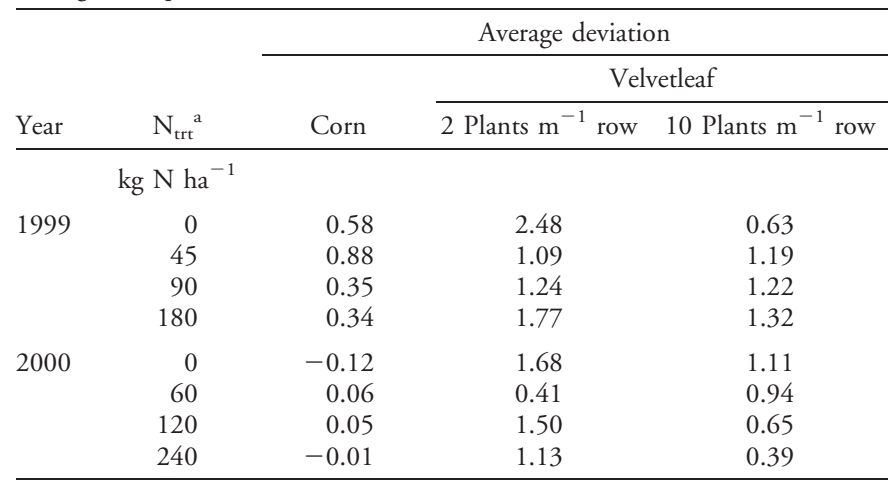

${ }^{\mathrm{a}} \mathrm{N}_{\text {tre }}, \mathrm{N}$ addition treatment. average deviations ranging from 39 to $248 \%$ of the observed values. Overall, the approaches to predicting $\mathrm{N}$ demand and distribution outlined here appear to be accurate for corn and velvetleaf. Further research is needed to incorporate these approaches into an ecophysiological model for interplant competition and to evaluate the entire model against independent experiments on corn-velvetleaf competition for $\mathrm{N}$ and light.

\section{Sources of Materials}

${ }^{1}$ LI-3000 area meter, LiCor, 4421 Superior Street, Lincoln, NE 68504-0425.

2 LECO CHN-2000, LECO Corporation, 3000 Lakeview Avenue, St. Joseph, MI 49085-2396.

${ }^{3}$ SAS Institute Inc., 100 SAS Campus Drive, Cary, NC 275132414.

\section{Acknowledgments}

This research is a contribution of the University of Nebraska Agricultural Research Division. This research was supported in part by funds provided by the Hatch Act and by the State of Nebraska.

\section{Literature Cited}

Baldwin, J. P., P. H. Nye, and P. B. Tinker. 1973. Uptake of solutes by multiple root systems from soil. III. A model for calculating the solute uptake by a randomly dispersed root system developing in a finite volume of soil. Plant Soil 38:621-635. 
Barker, D. C., S. Z. Knezevic, A. R. Martin, D. T. Walters, and J. L. Lindquist. 2006. Effect of nitrogen addition on the comparative productivity of corn and velvetleaf (Abutilon theophrasti). Weed Sci. 54:354-363.

Benbi, D. and J. F. Richter. 2002. A critical review of some approaches to modeling nitrogen mineralization. Biol. Fertil. Soils 35:168-183.

ten Berge, H. F. M., M. C. S. Wopereis, J. J. M. Riethoven, and H. Drenth. 1994. Description of the ORYZA_0 modules (version 2.0). Pages 43-55 in H. Drenth, H. F. M. ten Berge, and J. J. M. Riethoven, eds. ORYZA Simulation Modules for Potential and Nitrogen Limited Rice Production. Simulation and Systems Analysis for Rice Production (SARP) Research Proceeding. Wageningen, The Netherlands: DLO-Research Institute for Agrobiology and Soil Fertility, WAU-Department of Theoretical Production Ecology; Los Banos, Philippines: International Rice Research Institute.

ten Berge, H. F. M., T. M. Thiyagarajan, Q. Shi, M. C. S. Wopereis, H. Drenth, and M. J. W. Jansen. 1997. Numerical optimization of nitrogen application to rice. Part I. Description of MANAGE-N. Field Crops Res. 51:29-42.

Bonifas, K. D. and J. L. Lindquist. 2006. Predicting biomass partitioning to root versus shoot in corn and velvetleaf (Abutilon theophrasti). Weed Science 54:133-137.

Bonifas, K. D., D. T. Walters, K. G. Cassman, and J. L. Lindquist. 2005 Nitrogen supply affects root : shoot ratio in corn and velvetleaf (Abutilon theophrasti). Weed Sci. 53:670-675.

Brown, J. R. 1998. Recommended chemical soil test procedures for the North Central region. North Central Regional Publ. 221 (Revised). Columbia, MO: Missouri Agric. Exp. Stn.

Brown, R. H. 1978. A difference in $\mathrm{N}$ use efficiency in $\mathrm{C}_{3}$ and $\mathrm{C}_{4}$ plants and its implications in adaptation and evolution. Crop Sci. 18:93-98.

Brown, R. H. 1985. Growth of $\mathrm{C}_{3}$ and $\mathrm{C}_{4}$ grasses under low $\mathrm{N}$ levels. Crop Sci. 25:954-957.

Burns, I. G. 1980. Influence of the spatial distribution of nitrate on the uptake of $\mathrm{N}$ by plants: a review and a model for rooting depth. J. Soil Sci. 3:155-173.

Coleman, J. S., K. D. M. McConnaughay, and F. A. Bazzaz. 1993. Elevated $\mathrm{CO}_{2}$ and plant nitrogen-use: is reduced tissue nitrogen concentration sizedependent. Oecologia 93:195-200.

Davis, A. S. and M. Liebman. 2001. Nitrogen source influences wild mustard growth and competitive effect on sweet corn. Weed Sci. 49:558-566.

Ehleringer, J. R. and R. K. Monson. 1993. Evolutionary and ecological aspects of photosynthetic pathway variation. Ann. Rev. Ecol. Syst. 24:411-439.

Gastal, F. and G. Lemaire. 2002. N uptake and distribution in crops: an agronomical and ecophysiological perspective. J. Exp. Bot. 53:789-799.

Goldberg, D. E. 1990. Components of resource competition in plant communities. Pages 27-49 in J. B. Grace and D. Tilman, eds. Perspectives on Plant Competition. San Diego, CA: Academic.

Graf, B., A. P. Gutierrez, O. Rakotobe, P. Zahner, and V. Delucchi. 1990. A simulation model for the dynamics of rice growth and development. Part II. The competition with weeds for nitrogen and light. Agric. Sys. 32:367-392.

Greenwood, D. J., G. Lemaire, G. Gosse, P. Cruz, A. Draycott, and J. J. Neeteson. 1990. Decline in percentage $\mathrm{N}$ of $\mathrm{C}_{3}$ and $\mathrm{C}_{4}$ crops with increasing plant mass. Ann. Bot. 66:425-436.

Grime, J. P. 1979. Plant Strategies and Vegetation Processes. London: Wiley.

Harbur, M. M. and M. D. K. Owen. 2004. Light and growth rate effects on crop and weed responses to nitrogen. Weed Sci. 52:578-583.

Hasegawa, T. and T. Horie. 1996. Leaf nitrogen, plant age and crop dry matter production in rice. Field Crops Res. 47:107-116.

Jeuffroy, M. H., B. Ney, and A. Ourry. 2002. Integrated physiological and agronomic modeling of $\mathrm{N}$ capture and use within the plant. J. Exp. Bot. 53:809-823.

Kropff, M. J. 1993. Mechanisms of competition for nitrogen. Pages 77-82 in M. J. Kropff and H. H. van Laar, eds. Modelling Crop-Weed Interactions.
Wallingford, UK: CAB International; Los Banos, Philippines: International Rice Research Institute.

Lawlor, D. W. 2002. Carbon and nitrogen assimilation in relation to yield mechanisms are the key to understanding production systems. J. Exp. Bot. 53:773-787.

Lindquist, J. L. 2001a. Mechanisms of crop loss due to weed competition. Pages 233-253 in R. K. D. Peterson and L. G. Higley, eds. Biotic Stress and Yield Loss. Boca Raton, FL: CRC.

Lindquist, J. L. 2001b. Light-saturated $\mathrm{CO}_{2}$ assimilation rates of corn and velvetleaf in response to leaf nitrogen and development stage. Weed Sci. 49:706-710.

Lindquist, J. L. and D. A. Mortensen. 1999. Ecophysiological characteristics of four maize hybrids and Abutilon theophrasti. Weed Res. 39:271-285.

Lindquist, J. L., D. A. Mortensen, S. A. Clay, R. Schmenk, J. J. Kells, K. Howatt, and P. Westra. 1996. Stability of corn (Zea mays) —velvetleaf (Abutilon theophrasti) interference relationships. Weed Sci. 44:309-313.

McCullough, D. E., A. Aguilera, and M. Tollenaar. 1994. N uptake, N partitioning, and photosynthetic N-use efficiency of an old and a new corn hybrid. Can. J. Plant Sci. 74:479-484.

Montgomery, D. C. 1991. Design and analysis of experiments. 3rd ed. New York: John Wiley and Sons. Pp. 42-45.

Muchow, R. C. and T. R. Sinclair. 1994. Nitrogen response of leaf photosynthesis and canopy radiation use efficiency in field-grown corn and sorghum. Crop Sci. 34:721-727.

Nye, P. H. and P. B. Tinker. 1977. Solute movement in the soil-root system. Oxford, UK: Blackwell Scientific.

Radin, J. W. 1983. Control of plant growth by nitrogen: differences between cereals and broadleaf species. Plant Cell Environ 6:65-68.

Sage, R. F. and R. W. Pearcy. 1987a. The nitrogen use efficiency of $\mathrm{C}_{3}$ and $\mathrm{C}_{4}$ plants. I. Leaf nitrogen, growth, and biomass partitioning in Chenopodium album (L.) and Amaranthus retroflexus (L.). Plant Physiol 84:954-958.

Sage, R. F. and R. W. Pearcy. 1987b. The nitrogen use efficiency of $\mathrm{C}_{3}$ and $\mathrm{C}_{4}$ plants. II. Leaf nitrogen effects on the gas exchange characteristics of Chenopodium album (L.) and Amaranthus retroflexus (L.). Plant Physiol 84:959-963.

Sage, R. F., R. W. Pearcy, and J. R. Seeman. 1987. The nitrogen use efficiency of $\mathrm{C}_{3}$ and $\mathrm{C}_{4}$ plants. III. Leaf nitrogen effects on the activity of carboxylating enzymes in Chenopodium album (L.) and Amaranthus retroflexus (L.). Plant Physiol. 85:355-359.

Sheehy, J. E., M. J. A. Dionora, P. L. Mitchell, S. Peng, K. G. Cassman, G. Lemaire, and R. L. Williams. 1998. Critical nitrogen concentrations: implications for high yielding rice (Oryza sativa L.) cultivars in the tropics. Field Crops Res. 59:31-41.

Sinclair, T. R. and T. Horie. 1989. Leaf nitrogen, photosynthesis, and crop radiation use efficiency: a review. Crop Sci. 29:90-98.

Sinclair, T. R. and R. C. Muchow. 1995. Effect of nitrogen supply on maize yield: I. Modeling physiological responses. Agronomy J. 87:632-641.

Tilman, D. 1990. Mechanisms of plant competition for nutrients: the elements of a predictive theory of competition. Pages 117-141 in J. B. Grace and D. Tilman, eds. Perspectives on Plant Competition. San Diego, CA: Academic.

Wallace, A. 1990. Moisture levels, nitrogen levels_clue to the next limiting factor on crop production. J. Plant Nutr. 13:451-457.

Willigen, P. de. 1991. Nitrogen turnover in the soil-crop system; comparison of fourteen simulation models. Nutr. Cycl. Agroecosyst. 27:141-149.

Zhou, X. M., C. A. Madramootoo, A. F. MacKenzie, and D. L. Smith. 1997. Biomass production and nitrogen uptake in corn-ryegrass systems. Agron. J. 89:749-756.

Received August 17, 2006, and approved November 17, 2006. 